\title{
Uso das ervas e especiarias como estratégia para aumentar a biogênese mitocondrial, termogênese e recuperação muscular
}

- As ervas e especiarias são utilizadas para ofertar aromas e sabores aos alimentos, além de compostos bioativos que contribuem com a saúde mitocondrial e desempenho esportivo;

- O alto teor de polifenois das ervas e especiarias modulam a produção de energia (ATP), biogênese mitocondrial, termogênese e reduzem o estresse oxidativo e a dor muscular;

- Os ácidos ursólico, clorogênico, rosmarínico e a quercetina presentes em ervas e especiarias aumentam a expressão gênica de fatores de transcrição para biogênese mitocondrial;

- A biogênese mitocondrial é regulada pela ativação de AMPK, PGC-1 $\alpha$, SIRT-1, NRF1, NRF2, que propiciam a expressão gênica do fator de transcrição mitocondrial A (TFAM);

- Canela, gengibre, pimenta vermelha, cúrcuma e semente de mostarda são mais estudados pela ação em ativar os canais receptores de potencial transitório (TRP) e aumentar a termogênese;

- A dor muscular induzida pelo exercício pode ser modulada com o consumo de gengibre, canela, alho, cúrcuma e açafrão verdadeiro;

- A associação de várias ervas e especiarias garante uma melhor biodisponibilidade, ação antioxidante e outras ações terapêuticas devido ao sinergismo dos seus componentes;

- Na prática, as ervas e especiarias são usadas para marinar carnes, preparar bouquet garni, sachet d'epices, bebidas como sucos e chás e serem consumidas em refeições cruas ou cozidas.

\section{Referências bibliográficas}

1. OPARA, E.I.; CHOHAN, M. Culinary herbs and spices: their bioactive properties, the contribution of polyphenols and the challenges in deducing their true health benefits. Int J Mol Sci; 15(10):19183-202, 2014.

2. GIRALT, M.; CAIRÓ, M.; VILLARROYA, F. Hormonal and nutritional signalling in the control of brown and beige adipose tissue activation and recruitment. Best Pract Res Clin Endocrinol Metab; 30(4):515-525, 2016.

3. SANDOVAL-ACUÑA, C.; FERREIRA, J.; SPEISKY, H. Polyphenols and mitochondria: an update on their increasingly 5 emerging ROS-scavenging independent action. Arch Biochem Biophys; 559:75-90, 2014.

4. SAITO, M. Capsaicin and related food ingredients reducing body fat through the activation of TRP and brown fat thermogenesis. Adv Food Nutr Res; 76:1-28, 2015.

5. MEAMARBASHI, A. Herbs and natural supplements in the prevention and treatment of delayed-onset muscle soreness. Avicenna J Phytomed;7(1):16-26, 2017. 